Research article

urn:1sid:zoobank.org:pub:0956BCBF-1D81-46C4-94E4-C28550400077

\title{
Taxonomic revision of the Neotropical genus Ectophasiopsis Townsend, 1915 (Diptera: Tachinidae: Phasiinae)
}

\author{
Rodrigo de V.P. DIOS ${ }^{1, *} \&$ Silvio S. NIHEI ${ }^{2}$ \\ ${ }^{1,2}$ Department of Zoology, Institute of Biosciences, University of São Paulo, \\ Rua do Matão, Travessa 14, n. 101, São Paulo, SP, 05508-090, Brazil. \\ ${ }^{1}$ Corresponding author: rodrigodios@gmail.com \\ ${ }^{2}$ Email: silvionihei@gmail.com \\ ${ }^{1}$ urn:lsid:zoobank.org:author:16611E5E-DA51-44F1-8AC6-AE23554C2717 \\ ${ }^{2}$ urn:lsid:zoobank.org:author:377115F7-AA7C-45E0-BB44-A9143E8DEC2D
}

\begin{abstract}
The monotypic Neotropical genus Ectophasiopsis Townsend, 1915 (Diptera, Tachinidae, Phasiinae) is revised, with the addition of two species (one new and another transferred species), and a redefinition of the genus, accompanied by photographs and drawings of specimens and male terminalia. A new combination is proposed, Ectophasiopsis gradata (Wiedemann, 1830) comb. nov., previously Trichopoda Berthold, 1827, and a new species Ectophasiopsis ypiranga sp. nov. is described. A key for the genera of the "Trichopoda typica" subgroup sensu Sabrosky (1950), as well as a key to species of Ectophasiopsis is given. The geographical range of the genus and the host list are updated.
\end{abstract}

Keywords. Trichopodini, taxonomy, Neotropical, parasitoid.

Dios R. de V.P. \& Nihei S.S. 2017. Taxonomic revision of the Neotropical genus Ectophasiopsis Townsend, 1915 (Diptera: Tachinidae: Phasiinae). European Journal of Taxonomy 334: 1-27. https://doi.org/10.5852/ejt.2017.334

\section{Introduction}

The genus Ectophasiopsis was erected by Townsend (1915) to include a single new species from Chile, E. chilensis. Townsend commented that the genus was closely related to Trichopodopsis Townsend, 1913, now a synonym of Trichopoda Berthold, 1827. He also suggested that Trichopoda arcuata Bigot, 1876 could be a synonym of $E$. chilensis. Aldrich (1934) formally proposed that synonymy and pointed out the incorrect synonymy between T. arcuata and T. pennipes Fabricius, 1781, made by Brauer (1898), probably because the latter may not have seen the type (he mentioned "Plata" as the type-locality). Townsend (1936) did not consider Aldrich's (1934) synonymy and kept E. chilensis as a valid name and, moreover, placed Ectophasiopsis in the tribe Phasiini. Then, Townsend (1938) noted that the name T. arcuata sensu Aldrich (1934) could represent at least two species. Sabrosky (1950), after examining the male and female terminalia, stated that Ectophasiopsis was closer to Trichopodini than Phasiini. Dupuis (1963) kept Ectophasiopsis in the subtribe Trichopodina in his tribe Ectophasiini but as incertae sedis. In the Neotropical Catalogue, Guimarães (1971) placed the genus in Phasiini, following Townsend (1936). Currently, the genus Ectophasiopsis is monotypic with only E. arcuata (Bigot, 1876). 
The objective of this paper is to revise the genus Ectophasiopsis, to provide an identification key for the species and for the genera of the "Trichopoda typica" subgroup (sensu Sabrosky 1950) and to update the genus range and host list. In the revision, a new species is described from Brazil (E. ypiranga sp. nov.) and T. gradata Wiedemann, 1830 is transferred to Ectophasiopsis. The genus is here redefined to accommodate all three species.

\section{Material and methods}

The examined material is deposited at the following institutions:

CAS $=$ California Academy of Sciences, San Francisco, USA
CEIOC $=$ Coleção Entomológica do Instituto Oswaldo Cruz, Rio de Janeiro, Brazil
DZUP $=$ Coleção Entomológica Pe. Jesus Santiago Moure Curitiba, Brazil
INTA $=$ Instituto Nacional de Tecnologia Agropecuária, Castelar, Argentina
MNHN $=$ Muséum national d'Histoire naturelle, Paris, France
MZSP $=$ Museu de Zoologia da Universidade de São Paulo, São Paulo, Brazil
NHMW $=$ Naturhistorisches Museum Wien, Vienna, Austria
USNM $=$ National Museum of Natural History, Washington D.C., USA
ZMHB $=$ Museum für Naturkunde, Berlin, Germany

Additional material sent by researchers from agricultural research centers was also examined:

Dr. Ricardo Antonio Panizzi (EMBRAPA -Trigo)

Dr. Nelson Perioto (APTA Ribeirão Preto)

Dr. Enrique Castiglioni (EEMAC, Paysandú, Uruguay)

Dr. Jerson Guedes (UFSM)

All this material was deposited at MZSP.

Males and females of Trichopoda gradata comb. nov. and Ectophasiopsis ypiranga sp. nov. were dissected and illustrated. Only males of E. arcuata were dissected and illustrated due the availability of material. The holotype of T. gradata was examined by photo (sent by Dr. Peter Sehnal, NHMW), and the syntypes of $E$. arcuata were examined. The description of $T$. gradata comb. nov. was made based on a male identified by Wiedemann.

Specimens were photographed using a stereo microscope Leica MZ16 with an attached digital camera Leica model DFC420, using the software Leica Application Suite (LAS) Version 4.1.0 Build 1264. The images were subsequently stacked (merging different focal planes into one image) with the software Helicon Focus 5.3.14 (Kozub et al. 2000-2013) and later edited in Adobe Photoshop CS2. Measurements were also made with the LAS software. For each species, at least five males and five females were measured (depending on the availability of material); measurements provided in the descriptions were taken from the holotype and measurements of paratypes and / or additional specimens (non-types) are presented in the "Variation" sections. Illustrations were made using a stereo microscope Leica MZ16 with attached camera lucida, and later edited in Adobe Illustrator CS2. Final plates were prepared in Adobe Illustrator CS2.

For the study of male and female terminalia, specimens were first placed in a moist chamber for 48 to 72 hours, then the terminalia were dissected, placed into $10 \%$ solution of $\mathrm{KOH}$ and heated for 5 minutes. After that, to neutralize the $\mathrm{KOH}$, terminalia were put into $1 \%$ solution of acid alcohol for 15 seconds, and then washed and cleaned cautiously with water and a series of ethanol solutions of increasing concentrations. After examination, terminalia were stored in plastic microvials with glycerin and attached to the corresponding specimens. 
Terminology of morphology follows Cumming \& Wood (2009), and for antenna Stuckenberg (1999).

Individuals from the same locality and collector, but from different dates, are marked "ditto" and then the date is given for the set of specimens. Original labels are quoted between square brackets. The examined material is listed geographically from north to south for countries and states, and in alphabetical order for municipalities and localities.

Geographical data are based on the original labels and then georreferenced from Google Maps (when not available from labels). Distribution maps were prepared and edited in the software QGIS v.2.8 Valmiera (QGIS Development Team 2014).

\title{
Results
}

\author{
Class Hexapoda Blanville, 1816 \\ Order Diptera Linnaeus, 1758 \\ Family Tachinidae Bigot, 1853 \\ Genus Ectophasiopsis Townsend, 1915
}

\section{Systematic placement of Ectophasiopsis}

In recent classifications, the tribe Trichopodini is usually placed within Gymnosomatini, considering some shared characteristics of the male terminalia (Tschorsnig 1985). In the last morphological phylogeny of the family (Cerretti et al. 2014), those two tribes were grouped together in Gymnosomatini, with one apomorphy of the male terminalia (sperm duct developed into three well sclerotized ducts). In this morphological phylogeny, a single genus of Trichopodini was included (Trichopoda). The genus Ectophasiopsis shares most of the male terminalia characteristics with Trichopoda, including the sperm duct that is simple, the other two tubes are greatly reduced, to almost invisible, as Tschorsnig (1985) has already mentioned. More inclusive systematic studies, with wider sampling, are necessary to clarify these relationships.

The former tribe Trichopodini was divided by Sabrosky (1950) into three generic groups: Acaulonacomplex ( 7 genera), Trichopoda-complex (12 genera) and Xanthomelanodes-complex ( 2 genera). The Xanthomelanodes-complex was grouped by the presence of basal scutellar bristles widely divergent and much longer than the apical bristles; the Trichopoda-complex was grouped by the presence of a dorsal row of feather-like bristles on the posterior tibia; and the Acaulona-complex was grouped by the absence of those bristles.

Sabrosky also split the Trichopoda-complex into two subgroups: "Trichopoda typica" and "Trichopoda atypica". The subgroup "typica" included the genera Eutrichopoda Townsend, 1908, Trichopoda and Polistomyia (Townsend, 1908), the latter a junior synonym of Trichopoda; the subgroup "atypica" included the remaining genera. The "typica" subgroup is differentiated by a postcoxal area (between the hind coxae and first abdominal sternite) membranous and sunken or shriveled, and the front somewhat narrowed at vertex, the sides parallel on the basal half then suddenly diverging. The "atypica" subgroup have the postcoxal area closed (sclerotized) and the front different from that described for the other group (Sabrosky 1950).

Nowadays the valid genera in the "Trichopoda typica" subgroup sensu Sabrosky (1950) are Eutrichopoda and Trichopoda, and now we also include Ectophasiopsis in this group. Although a taxonomic revision of Eutrichopoda and Trichopoda was not the aim of the present study, those genera are included in the identification keys for that subgroup. Revisions of these genera are being made by the authors. 


\section{Key to genera of the subgroup "Trichopoda typica"}

1. Frontal vitta at vertex level usually wider than at lunula level, often yellow to light-tawny anteriorly. Wing with hyaline portion inside cell $\mathrm{dm}$ and forming a characteristic sinuosity in the hyaline border. Dm-cu crossvein almost straight or slightly curved. Claws dark-tawny with darker tips

Ectophasiopsis Townsend, 1915

- Frontal vitta at lunula level usually wider than at vertex level (or subequal), tawny to dark-tawny, at most with some lighter spots. Hyaline portion of wing outside cell dm (if inside, only slightly, not forming sinuosity). Dm-cu crossvein usually curved, sometimes even sinuous. Claws yellow to pale-tawny with black tips

2. Male: cerci weakly concave before posteromedian process, and posterolateral lobes absent or weakly developed. Postgonite distally very broad, in posterior view. Female: cerci thick, posteriorly flattened, with the flattened surfaces covered with rows of small setulae (for male and female terminalia, please see figures in Dios \& Nihei 2016) ................Eutrichopoda Townsend, 1908

- Male: cerci usually concave before posteromedian process, and posterolateral lobes developed or moderately developed. Postgonite distally moderately broadened, in posterior view. Female: cerci plate-like (sub-genus Galactomyia - resembling Ectophasiopsis, Fig. 3A-B), or cerci widely separated basally with converging apical portions elongate and slender, forceps-like (subgenus Trichopoda - see image of Polistomyia in Sabrosky 1950)

Trichopoda Berthold, 1827

Genus Ectophasiopsis Townsend, 1915

Ectophasiopsis Townsend, 1915: 439. Type species: Ectophasiopsis arcuata (Bigot, 1876) = chilensis Townsend, 1915.

Ectophasiopsis - Aldrich 1934: 11. — Townsend 1936: 55; 1938: 47. — Wolcott 1948: 271. — Sabrosky 1950: 361 (as Ectophasiops). — Dupuis 1963: 89. — Guimarães 1971: 12.

\section{Redefinition}

Coloration. Frontal vitta often yellow to light-tawny anteriorly. Wing with strong yellow radiation always starting at base. Wing with hyaline portion inside cell $\mathrm{dm}$ and forming a characteristic sinuosity in hyaline border. Claws brown to dark-tawny, black distally.

HeAd. Eyes dichoptic in both sexes. Frontal vitta wider (or only slightly wider) anteriorly, narrowing in middle and diverging posteriorly; wider at vertex level than at lunule level (sometimes subequal). Pair of ocellar setae thin and divergent. Fronto-orbital plate bare; wider anteriorly. Vibrissa present, shorter than length of arista. Antennal axis subequal to oral axis. Postpedicel reniform rounded, slightly flattened laterally, little longer than scape and pedicel together.

Thorax. Intra-alar setae $0+1$; supra-alar setae $1+1 ; 2$ postalar setae. Scutellum with one pair of basal setae and one pair of subapical setae. Postcoxal bridge membranous.

WING. Cell $\mathrm{r} 4+5$ closed and short petiolate, meeting wing margin a little before apex. Crossvein $\mathrm{dm}-\mathrm{cu}$ straight to slightly sinuous. Posterior border of lower calypter slightly concave, external lobe enlarged. Legs. Fore tibia with two rows of dorsal feather-like setae, one outer with very short setae and inner much longer. Claws in male straight elongate and curved at tip and pulvilli elongate, squared, almost same length as claw; in female claws short and curved, and pulvilli shorter and rounded.

ABDOMEN. Elliptical to rounded, dorsoventrally flattened, tergites $1+2$ to tergite 6 visible dorsally, without strong differentiated setae. Sternites free and membrane exposed. 
Male terminalia. Cerci with posteromedian process and slightly broadened posterolateral lobes; posteromedian process with an anterior notch in lateral view, distally flattened, large and rounded in lateral view. Pregonite and postgonite fused. Postgonite slightly widened apically and rounded in posterior view. Distiphallus as a membrane-covered complex of two sclerotized plates distally opened 'Halbschalen' in Tschorsnig 1985) that surrounds a sclerotized inner tube: one as an outer half-tubelike plate with a large opening on right-posterior portion; other as an inner sclerotized ring-like plate, dorsally invaginated following sclerotized inner tube through its entire extent, indented with slender transversal slit on right side. Sclerotized inner tube simple ('Samenleiter' in Tschorsnig 1985), dorsally bulbous, outside ring-like plate, bending and becoming straight inside ring-like plate, sometimes a little curved; dorsally it is connected to spermatic duct that goes along with aedeagus and connects with spermatic pump (as in other genera of 'Trichopoda typica' group).

Female terminalia. Sternite and tergite 7 not fused. Sternite 8 short, rounded distally. Cercus flattened plate-like, subquadrate, with lateral projections; connected to base of sternite 8 by a thin sclerotized strip. Epiproct and hypoproct absent.

\section{Key to species of Ectophasiopsis Townsend, 1915}

1. Ratio of frontal vitta width at level of lunula/width at vertex level of 0.8 to 0.9 . Dorsocentral setae $2+2$ or $3+2$ (presutural setae short). Thorax long setulose dorsally and laterally. Male: hind femur with posteroventral setae long and slightly flattened ............E. arcuata (Bigot, 1876)

- Ratio of frontal vitta width at level of lunula/ width at vertex level of 0.55 to 0.75 . Dorsocentral setae $1+1$ or $1+2$. Thorax short setulose. Male: hind femur with posteroventral setae short ...............

2. Antennal axis longer (Figs 7C, 8C), fronto-orbital plate at lunule level and parafacial enlarged (Fig. 1C). Male: cerci midventral opening lateral border not visible in dorsal view (Fig. 1A) ...

E. gradata (Wiedemann, 1830) comb. nov.

- Antennal axis shorter (Figs 9C, 10C, 11C), fronto-orbital plate at lunule level and parafacial narrowed (Fig. 1D). Male: cerci midventral opening lateral border visible in dorsal view, as a small lappet (Fig. 1B)

E. ypiranga sp. nov.

Ectophasiopsis arcuata (Bigot, 1876)

Figs 2A-E, 4-6

Trichopoda arcuata Bigot, 1876: 397. Lectotype Ô, BMNH (other "syntypes" misidentified; see discussion below). Type locality: "Chile" (examined).


"Chile". (syn. by Aldrich 1934).

Trichopoda arcuata - Townsend 1893: 70; 1915: 439. — Guimarães 1971: 12.

Ectophasiopsis chilensis - Townsend 1915: 439; 1936: 55; 1938: 47. — Aldrich 1934: 12. — Guimarães 1971: 12.

Ectophasiopsis arcuata - Aldrich 1934: 12. — Wolcott 1948: 471. — Guimarães 1971: 12.

\section{Diagnosis}

Ectophasiopsis arcuata closely resembles E. gradata comb. nov. as both have the antennal axis longer and fronto-orbital plate at the lunule level and parafacial enlarged, but differs from other species by the thorax being long setulose laterally and dorsally and dorsocentral setae $2+2$ or $3+2$ (short presutural setae). 


\section{Type material examined}

\section{Lectotype}

CHILE: Ô, T. arcuata (BMNH) by present designation. "Syntype" (white label with blue border); ["Brauer / Wien. CVII. / (No. 105)" "Trichopoda / arcuata Bigot / syntype § / Chile, Plata / ex. Bigot Coll: / B.M. 1960-539"; "T. arcuata / Chili, Plata. J. Bigot [white with black border]" "BMNH (E) \# / 230866"; "Lectotype / Ectophasiopsis arcuata (Bigot) / R. Dios des. 2016"].

\section{Additional material examined}

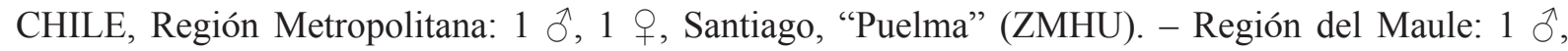
Cauquénes, 20 Nov. 1997, S. Schönemann leg. (ZMHU) (dissected); 1 \&, ditto, 6 Aug. 1999 (ZMHU); 10 , Caiablo or Carablo (illegible), Jan. 1954, E.P. Reed leg. (CAS).

A

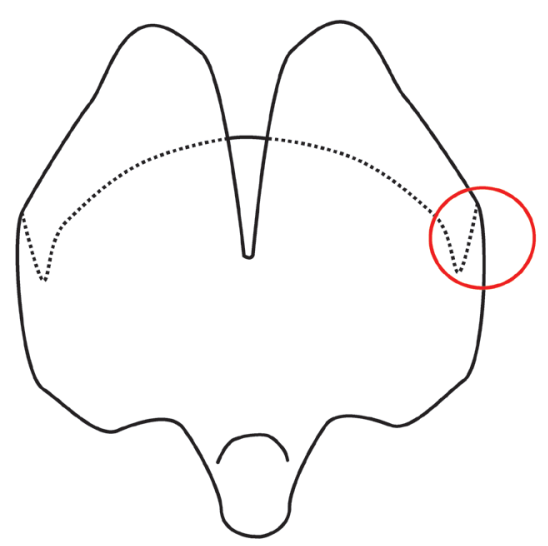

$\mathrm{B}$

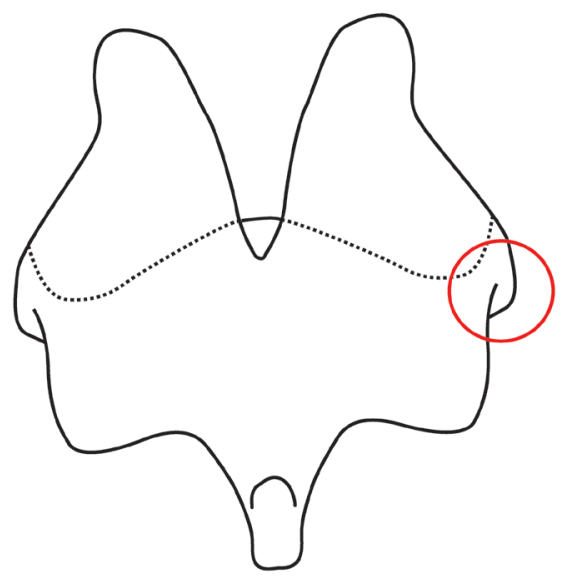

$\mathrm{C}$



$\mathrm{D}$

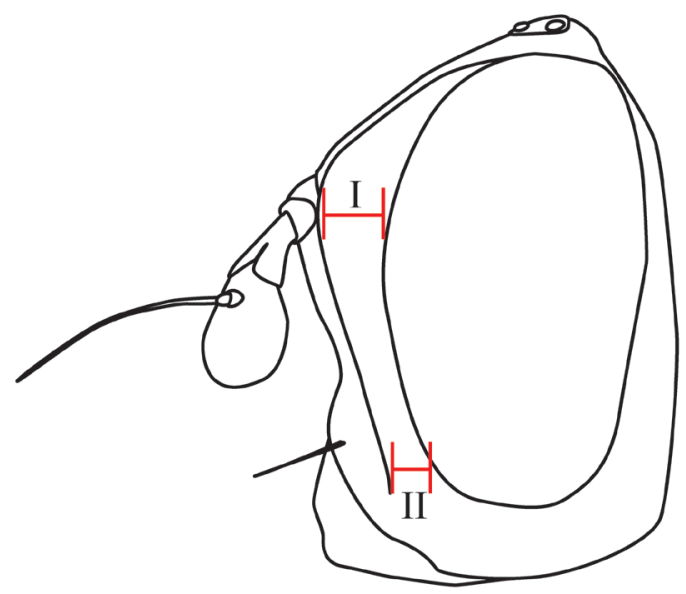

Fig. 1. A. Male cerci of Ectophasiopsis gradata (Wiedemann, 1830) comb. nov., dorsal view; red circle indicates the midventral opening, the lateral border is not visible in dorsal view. B. Male cerci of E. ypiranga sp. nov., dorsal view; red circle indicates the midventral opening, the lateral border is visible in dorsal view as a small laplet. C. Head of E. gradata (Wiedemann, 1830) comb. nov., lateral view. Red bars showing width of fronto orbital plate at the lunule level (I) and parafacial (II). D. Head of E. ypiranga sp. nov., lateral view. Red bars show the width of the fronto orbital plate at the lunule level and parafacial. Scale bars: $A-B=0.2 \mathrm{~mm} ; \mathrm{C}-\mathrm{D}=1 \mathrm{~mm}$. 


\section{Redescription}

Male (Fig. 5)

Body LENGTH. $6.9 \mathrm{~mm}$ (lectotype), 7.3-7.6 mm $(\mathrm{n}=3)$.

Coloration. Frontal vitta yellowish-tawny with region around ocellar triangle dark brown to black. Ocellar triangle black. Fronto-orbital plate light-tawny to orange with silver and light-golden pruinosity. Parafacial and gena light-tawny-yellow with silver pruinosity. Antenna tawny-yellow, with area close to joints and posterior part of postpedicel slightly yellowish-orange. Palpus tawny to light-tawny. Presutural scutum dark brown to black (lacking pruinosity probably due to effects of preservation), with light-golden pruinosity delimiting two diverging median black stripes fused anteriorly and two triangular lateral black spots. Postpronotal lobe dark brown with silver pruinosity. Postsutural scutum dark brown, with light-golden pruinosity delimiting two central small triangular black spots and two outer long triangular black spots. Scutellum dark brown to black with silver pruinosity. Thorax laterally brown to black with silver pruinosity. Wings with orange-yellow radiation from the base to little beyond vein $\mathrm{r}-\mathrm{m}$ anteriorly and little beyond vein bm-cu posteriorly, followed by infuscate band ranging from anal lobe to almost apex of cell $\mathrm{r} 4+5$ and posterior border hyaline; hyaline part extending to cell $\mathrm{dm}$ and $\mathrm{r} 4+5$. Calypters orange-yellow, basally lighter. Legs brown, coxae with silver pruinosity; pulvilli pale-tawny to brown. Abdomen yellow-orange; tergite 1 dark brown; tergite 4 posteriorly dark brown; dorsal median longitudinal dark brown line between tergite 1 and 4; tergite 5 dark brown, but orange on posterior lateral margins and thin median posterior dark brown line; tergite 6 orange yellow with thin median anterior dark brown stripe; silver and light-golden pruinosity on tergites 5 and 6 , and scarcely on tergite 4 posteriorly. Abdomen ventrally with almost same pattern as dorsally, without pruinosity.

HEAD. Ratio of head width / thorax width dorsally of 1.35. Ratio of head length/head width 0.5 . Ratio of frontal vitta width at level of lunula/width at vertex level 0.8. Fronto-orbital plate width subequal to frontal vitta width at level of lunula. Antennal axis long, fronto-orbital plate at lunule level and parafacial enlarged. Ratio of gena height/ eye height 0.16 .

Thorax. Acrostichal setae apparently $0+0$ (area damaged by pin; $0+1$ in non-types, sometimes weak); dorsocentral setae $3+2$; all thorax long setulose, almost same length as setae. Postpronotal lobe damaged by pin (3 setae on non-types). Two katepisternal setae.

WING. Subtriangular, anal lobe slightly larger. Ratio of wing length/wing maximum width 2.37 . Crossvein dm-cu straight.

Legs. Hind femur with row of anterodorsal setae, one preapical anteroventral seta and row of posteroventral setae on apical third, some setae slightly flattened; hind tibia with one median anteroventral seta and one median posterodorsal setae; row of longer feather-like setae covering apical 0.76 , length of longest feather-like seta 1.77 times the tibial width.

AвDOMEN. Elliptical, little rounded, dorsoventrally flattened. No differentiated setae, only small setae laterally on tergites posterior margins. Ratio of abdomen length/thorax length 1.39. Ratio abdomen width/thorax width 1.33. Ratio of abdomen length/abdomen width 1.37 .

Terminalia (Fig. 2A-E). Cerci midventral opening lateral border not visible in dorsal view. Postgonite almost not enlarged distally in posterior view, subequal in its length. Phallapodeme subequal in its length, slightly widened apically. Basiphallus as an incomplete ring, open posteriorly.

\section{Variation}

Coloration. Frontal vitta and postpedicel sometimes darker. Presutural scutum with median black stripes fused. Postpronotal lobe lighter brown. Postsutural scutum sometimes posteriorly all dark brown 

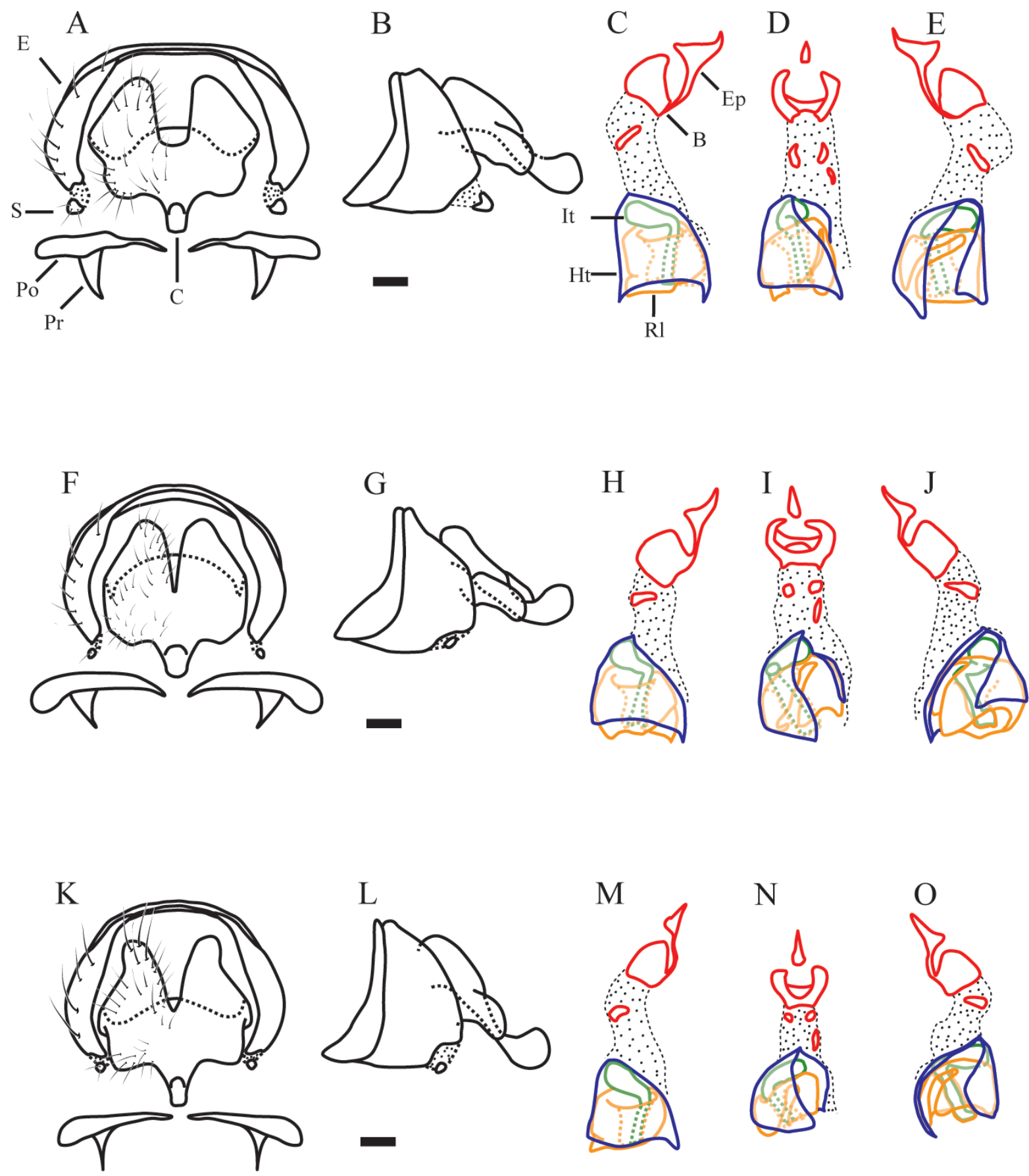

Fig. 2. Male terminalia. - A-E. Ectophasiopsis arcuata (Bigot, 1876). A. Epandrium, cerci, surstyli, pregonite and postgonite, posterior view. B. Epandrium, cerci and surstyli, lateral view. C. Phallus, right lateral view. D. Phallus, posterior view. E. Phallus, left lateral view. - F-J. E. gradata (Wiedemann, 1830) comb. nov. F. Epandrium, cerci, surstyli, pregonite and postgonite, posterior view. G. Epandrium, cerci and surstyli, lateral view. H. Phallus, right lateral view. I. Phallus, posterior view. J. Phallus, left lateral view. - K-O. E. ypiranga sp. nov. K. Epandrium, cerci, surstyli, pregonite and postgonite, posterior view. L. Epandrium, cerci and surstyli, lateral view. M. Phallus, right lateral view. N. Phallus, posterior view. O. Phallus, left lateral view. Abbreviations: $\mathrm{B}=$ basiphallus (red color); $\mathrm{C}=$ cerci; $\mathrm{E}=$ epandrium; $\mathrm{Ep}=$ epiphallus (red color); $\mathrm{Ht}=$ half-tube like plate (blue color); $\mathrm{It}=$ sclerotized inner tube (green color); $\mathrm{Po}=$ postgonite; $\mathrm{Pr}=$ pregonite; $\mathrm{Rl}=$ ring-like plate (orange color); $\mathrm{S}=$ surstylus. Scale bars: $0.2 \mathrm{~mm}$. 
to black. Wing with orange-yellow coloration pale; infuscate band more diffuse, cell $\mathrm{dm}$ posteriorly weak infuscate and hyaline. Abdomen with dorsal median longitudinal dark brown line wider, tergite 6 without brown markings, and varying pruinosity.

HEAD. Ratio of head width/ thorax width dorsally 1.35 to 1.52 . Fronto-orbital plate width little wider than frontal vitta width at level of lunula. Ratio of gena height / eye height 0.13 to 0.16 . Thorax. Dorsocentral setae $2+2$.

WING. Ratio of wing length/wing maximum width 2.19 to 2.57 .

LEGS. Fore femur with rows of short posterodorsal and posteroventral setae sometimes very weak. Hind femur with preapical anteroventral seta not differentiated and row of posteroventral setae on apical third with varied sizes and lengths. Row of long feather-like setae on hind tibia covering apical 0.76 to 0.9 of tibia, and length of longest feather-like seta 1.51 to 1.77 times tibial width. Abdomen. Ratio of abdomen length/thorax length 1.32 to 1.39 . Ratio abdomen width / thorax width 1.33 to 1.68 . Ratio of abdomen length/abdomen width 1.15 to 1.37 .

Female (Fig. 6)

Differs from male as follows:

Body Length. 6.6-7.3 mm $(\mathrm{n}=2)$.

Coloration. Head with silver pruinosity only and background color usually darker. Thorax darker, with silver pruinosity, sometimes scarce as two longitudinal thin lines; Postsutural scutum all dark brown to black posteriorly. Wings sometimes paler orange-yellow, extending a little less than in males; hyaline border wider and clearly defined. Abdomen yellow-orange, dorsal median longitudinal dark brown line ending in middle of tergite $1+2$; tergite 4 with median dorsal dark brown black triangle pointing anteriorly; tergite 5 and 6 dark brown to black.

Thorax. Postpronotal lobe with 2 setae, sometimes a third very weak.

WING. Elliptical.

LEGS. Hind femur with row of posteroventral setae on apical third, never flattened; hind tibia with length of longest feather-like seta 2.11 times tibial width. Claws shorter and curved. Pulvilli shorter, more rounded.

ABDOMEN. Elliptical. Very weakly differentiated median marginal setae on tergite 4 to tergite 6 . Slightly shorter (ratio of abdomen length/thorax length 1.21 to 1.28) and narrower (ratio abdomen width/thorax width 1 to 1.2). Ratio of abdomen length/abdomen width 1.31 to 1.6.

Terminalia. Due to lack of material, no female was dissected.

\section{Distribution (Fig. 4)}

Chile, and introduced in Puerto Rico (Wolcott 1948). The species was also introduced to Easter Island, from mainland Chile (Ripa et al. 1995)

\section{On the type specimens of $E$. arcuata and its identity}

There has been confusion surrounding the type material of Ectophasiopsis arcuata ( 7 syntypes). Bigot's (1876) original description did not state the number of specimens examined nor did he describe any variation (e.g., in the color of the abdomen and wings). Aldrich (1934) examined the types of E. chilensis and E. arcuata, without mentioning their labels and localities. Now we have had the opportunity to study the entire type series borrowed from BMNH and we could observe that actually only one syntype is 
labeled from "Chile, Plata" and bears Bigot's characteristic identification label with the black border (see Crosskey 1971). This syntype is the only one that fits the original description so, in the interests of nomenclatural stability, is designated here as the lectotype of Trichopoda arcuata Bigot, 1876. The other six syntypes of arcuata are now paralectotypes, but all them were misidentified by Bigot: one is a Trichopoda sp. while the remaining five are E. gradata (Wiedemann, 1830) comb. nov. These six paralectotypes bear two labels: ["Brauer / Wien. CVII. / (No. 105)"] and ["Syntype"] (round label from $\mathrm{BMNH}$ ), but not Bigot's identification labels. However, in Verrall's handwritten notes about Bigot's type collection, he stated that there were seven specimens in the Trichopoda arcuata type series (Adrian Pont, pers. comm.). It is likely that these six paralectotypes might be Brauer's further addition to the type series, but we cannot state it with certainty. Therefore, we assume that the seven specimens belong to Bigot's type series of E. arcuata and it involves three different identities. Townsend (1938) had stated earlier that the types of E. arcuata could represent at least two species.

Ectophasiopsis gradata (Wiedemann, 1830) comb. nov.

Figs 1A, C, 2F-J, 3A, 4, 7-8

Trichopoda gradata Wiedemann, 1830: 275. Holotype , NHMW. Type locality: "Brasil".

Trichopodopsis argentinensis Blanchard, 1966: 65. Holotype ô, INTA (examined). Type locality: Argentina, Córdoba.

Trichopodopsis incognita Blanchard, 1966: 62. Holotype + , probably lost. Type locality: Argentina, La Rioja.

Trichopodopsis christenseni Blanchard, 1966: 78. Holotype đ̂, INTA. Type-locality: Argentina, José C. Paz leg. (examined).

Trichopoda gradata - Walker 1853: 258.

Ectophasiopsis arcuata - Aldrich 1934: 12 (part, misidentification).

Trichopoda (Trichopoda) gradata - Guimarães 1971: 9.

Trichopoda argentinensis - Liljesthröm 1992: 51.

Trichopodopsis incognita - Liljesthröm 1992: 51.

Trichopodopsis christenseni - Liljesthröm 1992: 51.

Trichopoda (Galactomyia) argentinensis - Guimarães 1971: 10.

Trichopoda (Trichopoda) incognita - Guimarães 1971: 10.

Trichopoda (Galactomyia) christenseni-Guimarães 1971: 10.

\section{Diagnosis}

Ectophasiopsis gradata comb. nov. closely resembles E. arcuata as both have the antennal axis longer and the fronto-orbital plate at the lunule level and parafacial enlarged, but differs from E. arcuata by having the thorax short setulose laterally and dorsally, and dorsocentral setae $1+2$.

Ectophasiopsis gradata comb. nov. closely resembles E. ypiranga sp. nov. as both have the thorax short setulose laterally and dorsally, dorsocentral setae 1+2, but differs from E. ypiranga sp. nov. by having the antennal axis longer; fronto-orbital plate at the lunule level and parafacial enlarged; cerci midventral opening lateral border not visible in dorsal view; and posterolateral lobes usually less developed.

\section{Type material examined}

Holotype of T. gradata $q$ (NHMW). ["gradrata (misspelling) Wd. / T. q. / Coll. Winthem"; "Brasilia"; "Holotype / Trichopoda / gradata / examind 1999 / P. Sehnal" (red label)].

Holotype of T. argentinensis đ̂ (INTA). ["Holótipo" (red label); “Córdoba / ii.1920”; “232”; "Holotypus”; "Trichopodopsis argentinensis / Blnchd / det. E. E. Blanchard"]. Head damaged; left wing broken; 
lacking right wing, only with left mid leg and right fore leg; abdomen broken. Right wing mounted on microscope slide. Terminalia dissected in a vial, missing cerci, phallapodeme broken.

Holotype of T. christenseni § (INTA). ["Holótipo" (red label); "J. C. Paz / iii.1939 / Christensen"; "Athaumastus"; "234"; "Holotypus"; "Trichopodopsis christenseni / Blnchd / det. E. E. Blanchard"]. Lacking right wing, right fore leg and both hind legs. Right wing mounted on microscope slide. Terminalia dissected in a vial, phallapodeme broken.

\section{Additional material examined}

BRAZIL, Paraná: $2 \widehat{\jmath}, 1$ + , Bela Vista do Paraíso, host Dichelops melacanthus, 27 Oct. 2008, Pavão leg. (DZUP) (1 đo dissected); 1 ô, Laranjeiras do Sul, Jan.1962, S. Sakagami leg. (DZUP). - Santa

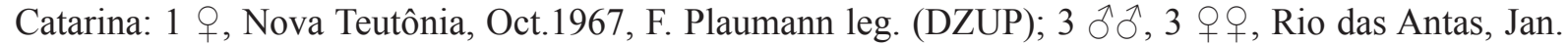

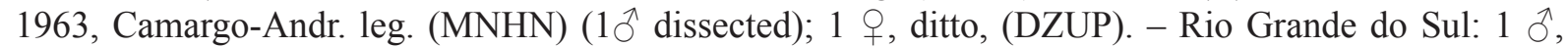
3 우, Passo Fundo, host Dichelops furcatus, 24 Oct. 2014, A. Agostinetto leg. (MZSP) (1 $\delta^{1}$ and 1 ㅇ

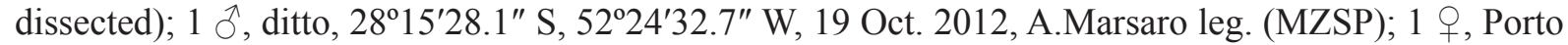
Alegre, $30^{\circ} 05^{\prime} 38.2^{\prime \prime} \mathrm{S}, 51^{\circ} 13^{\prime} 07.8^{\prime \prime} \mathrm{W}$, host: Dichelops furcatus, 30 Sep. 2012, A. Marsaro leg. (MZSP).

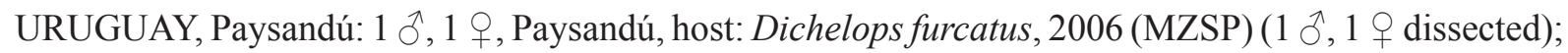

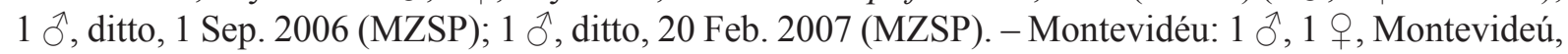
Sello leg. (ZMHU).

ARGENTINA, Santa Fé: 1 +, Carcarañá, 13 Apr. 1910 (ZMHU). - Santigo del Estero: 1 \&, Averias, 1914, E.R. Wagner leg. (MNHN); 1 đ̂, Banderas, 1910, E.R. Wagner leg. (MNHN); 1 o, 1 †, Icaño, (surroundings of) Guarda Escolta, 1909, E.R. Wagner leg. (MNHN); 1 ô, 1 क , margins of Salado River, 1904, E.R. Wagner leg. (MNHN); 2 $\widehat{\partial}$, ditto, 1909 (MNHN) (10ิ dissected).

Male (Fig. 7)

Body LENGTH. $7.5 \mathrm{~mm}$ (holotype) 6.4-7.2 $\mathrm{mm}(\mathrm{n}=5)$.

Coloration. Frontal vitta light-tawny with region around ocellar triangle dark brown to black. Ocellar triangle black. Fronto-orbital plate light-tawny to orange with light-golden pruinosity. Parafacial lighttawny with light-golden pruinosity on upper half and silver pruinosity on lower half. Gena light-tawny


Fig. 3. Female terminalia. A. Ectophasiopsis gradata (Wiedemann, 1830) comb. nov. B. E. ypiranga sp. nov. Abbreviations: $\mathrm{C}=\mathrm{Cerci}$; $7=$ Sternite 7 ; $\mathrm{s} 8=$ Sternite 8 . Scale bars: $0.2 \mathrm{~mm}$. 
with silver pruinosity. Scape and pedicel tawny-yellow; postpedicel brown with base and posterior part slightly orange. Palpus light-tawny to pale yellow. Presutural scutum covered with light-golden pruinosity delimiting two diverging median black stripes fused anteriorly and two triangular lateral black spots. Postpronotal lobe covered with light-golden pruinosity. Postsutural scutum tawny to brown, tawny-yellow on sides; with light-golden pruinosity delimiting two median small triangular black spots and two outer long triangular black spots. Scutellum dark brown to black with silver pruinosity. Thorax laterally brown to black with silver pruinosity. Wings with orange-yellow radiation from base to sc anteriorly, beyond vein r-m medialy and little beyond vein bm-cu posteriorly; followed by infuscate band ranging from anal lobe almost to apex of wing, little beyond cell $\mathrm{r} 4+5$, and posterior border hyaline; hyaline part extending to cell $\mathrm{dm}$. Calypters pale-yellow. Legs brown, coxae with silver pruinosity, trochanters and base of mid and hind-femora tawny-yellow; pulvilli pale-brown. Abdomen yellow-orange; tergite 1 medially with light-brown marking; tergite 2 with brown longitudinal median line, almost reaching margin; tergite 3 with brown median posterior triangle marking, expanding transversely between tergite 3 and 4; tergite 4 with brown trapezoidal median marking; tergite 5 with brown rectangular marking; tergite 6 with sparce light-golden pruinosity. Abdomen ventrally pale yellow, sternite 5 to rear end tawny.

HEAD. Ratio of head width/thorax width dorsally of 1.4. Ratio of head length/head width 0.5 . Ratio of frontal vitta width at level of lunula/width at vertex level 0.7. Fronto-orbital plate width wider than frontal vitta width at level of lunula. Antennal axis long, fronto-orbital plate at lunule level and parafacial enlarged. Ratio of gena height/ eye height 0.17 .



Fig. 4. Distribution map of Ectophasiopsis species. E. arcuata (Bigot, 1876) = yellow dots; E. gradata (Wiedemann, 1830) comb. nov. = green dots; E. ypiranga sp. nov. $=$ red dots. 
Thorax. Acrostichal setae $0+1$ (area damaged by pin, $0+1$ on non-types); dorsocentral setae $1+2$. Postpronotal lobe with 2 setae. Two katepisternal setae.

WING. Elliptical, anal lobe larger. Ratio of wing length/wing maximum width 2.57. Crossvein dm-cu straight.

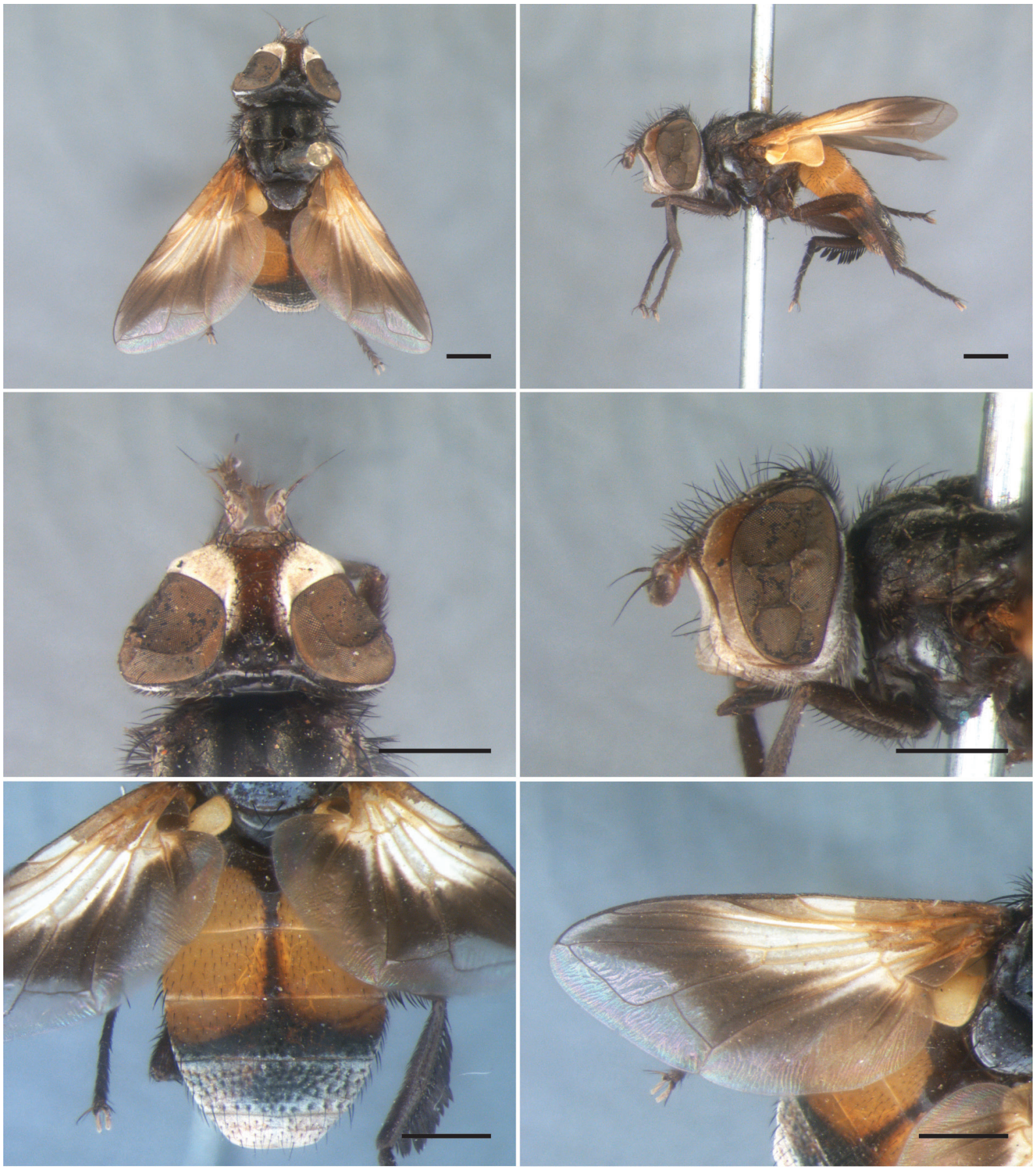

Fig. 5. Ectophasiopsis arcuata (Bigot, 1876), ô, lectotype, Chile, "Plata", BMNH. A. Dorsal view. B. Lateral view. C. Head, dorsal view. D. Head, lateral view. E. Abdomen, dorsal view. F. Wing, dorsal view. Scale bars: $1 \mathrm{~mm}$. 
LEGS. Hind femur with row of short anterodorsal setae and row of weak posteroventral setae on apical third; hind tibia with one median anteroventral seta and one median posterodorsal setae; row of longer feather-like setae covering apical 0.75 of tibia, and length of longest feather-like seta 1.41 times tibial width.


Fig. 6. Ectophasiopsis arcuata (Bigot, 1876), $q$, Chile, Santiago, ZMHU. A. Dorsal view. B. Lateral view. C. Head, dorsal view. D. Head, lateral view. E. Abdomen, dorsal view. F. Wing, dorsal view. Scale bars: $1 \mathrm{~mm}$. 
AвDOMEn. Rounded, somewhat elliptical, dorsoventrally flattened. No differentiated setae. Ratio of abdomen length/thorax length 1.35. Ratio abdomen width/thorax width 1.41. Ratio of abdomen length/abdomen width 1.27 .

Terminalia (Fig. 2F-J). Cerci midventral opening lateral border not visible in dorsal view; posterolateral lobes usually less developed. Postgonite slightly enlarged distally in posterior view. Phallapodeme widened anteriorly. Basiphallus forming a complete ring, fused posteriorly.

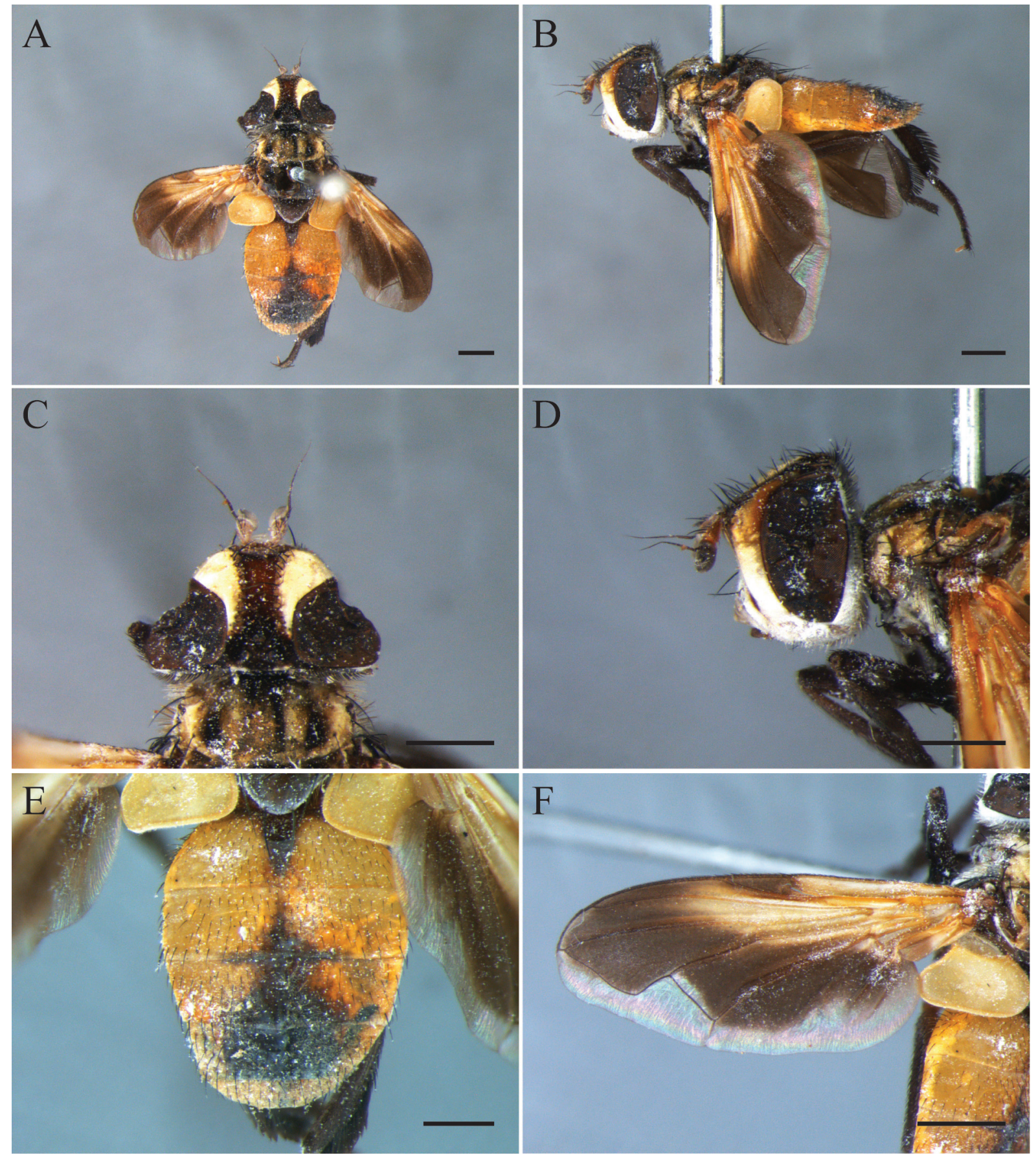

Fig. 7. Ectophasiopsis gradata (Wiedemann, 1830) comb. nov., §̂, Uruguay, Montevidéu, ZMHU. A. Dorsal view. B. Lateral view. C. Head, dorsal view. D. Head, lateral view. E. Abdomen, dorsal view. F. Wing, dorsal view. Scale bars: $1 \mathrm{~mm}$. 


\section{Variation of male}

Coloration. Frontal vitta orange-tawny to dark-brown. Fronto-orbital plate and parafacial pruinosity darker. Scutum covered with golden or dark-golden pruinosity; Presutural scutum with median black stripes sometimes not fused anteriorly. Scutellum sometimes with apex lighter. Wings with orangeyellow radiation varying in intensity; infuscate band darker, almost black, sometimes not beyond cell $\mathrm{r} 4+5$; hyaline part sometimes enters cell $\mathrm{r} 4+5$. Calypters orange-yellow. Trochanters and base of femora sometimes light-yellow. Tergite 1 without brown marking; tergite 2 without brown longitudinal median line; tergite 3 without brown markings, sometimes with brown median longitudinal line or sometimes brown irregular marking; tergite 4 fully brown or with brown markings posteriorly varying in size, and / or with brown longitudinal line; tergite 5 fully brown; light-golden pruinosity sometimes also on tergite 5 and sparse on tergite 4.

HEAD. Ratio of head width / thorax width dorsally 1.31 to 1.4. Ratio of head length / head width 0.48 to 0.54 . Ratio of frontal vitta width at level of lunula/width at vertex level 0.63 to 0.74 . Fronto-orbital plate width sometimes little wider than frontal vitta width at level of lunula. Ratio of gena height / eye height 0.17 to 0.2 .

WING. Ratio of wing length/wing maximum width 2.65 to 2.75 . Crossvein dm-cu sometimes slightly sinuous.

LEGS. Hind femur with row of short anterodorsal setae only on distal half and row of posteroventral setae on apical third almost not differentiated; hind tibia with row of longer feather-like setae covering apical 0.75 to 0.8 of tibia, length of longest feather-like seta 1.41 to 1.87 times tibial width.

AвDomen. Sometimes more elliptical, and dorsoventrally less flattened. Some specimens with longer marginal setulae on tergites 4 and 5. Ratio of abdomen length/thorax length 1.35 to 1.65 . Ratio abdomen width/thorax width 1.14 to 1.41 . Ratio of abdomen length/abdomen width 1.27 to 1.8 .

Female (Fig. 8)

Differs from male as follows:

Body LeNGTH. 6.1-7.7 mm $(\mathrm{n}=5)$.

Coloration. Postsutural scutum pruinosity sometimes scarcer, as two longitudinal thin lines. Sometimes wings with weak orange-yellow radiation, strong only at wing base. Abdomen yellow-orange, darkbrown to black distally; tergite 3 usually with small triangular median posterior spot, rarely absent; tergite 4 mostly dark, only anterior lateral margins yellow-orange, varying in extent; tergite 5 to abdomen tip fully dark-brown to black, rarely with irregular yellow-orange spots.

Abdomen. Elliptical, sometimes slightly ovate. Ratio of abdomen length/thorax length 1.23 to 1.39. Slightly narrower (ratio of abdomen width/thorax width 1.17 to 1.31 ) and usually shorter (ratio of abdomen length/thorax length 1.23 to 1.39 ).

Terminalia (Fig. 3A). Sternite 8 short, rounded distally, with small less sclerotized spot ventrally.

Distribution (Fig. 4)

Brazil (Paraná, Santa Catarina, Rio Grande do Sul), Uruguay and Argentina.

\section{Remarks}

The male specimen from Montevidéu (ZMHU) was chosen as the basis of the species description as it has a determination label "gradata" handwritten by Wiedemann. The holotype of E. gradata comb. nov. 
from "Brazil", deposited at NHMW, is a female and was examined from photos kindly sent by Peter Sehnal (curator). The external features, especially the size and shape of the fronto orbital plate and parafacial in lateral view, were decisive in grouping the species. The holotype of $T$. argentinensis is damaged, but we could observe that it is conspecific with E. gradata comb. nov. The male terminalia (with the cerci lost) had already been dissected and preserved in a vial, pinned alongside the specimen. The holotype male of T. christenseni is better preserved and the synonymy is based on the external features, as well as the terminalia, which were found dissected and fully preserved.

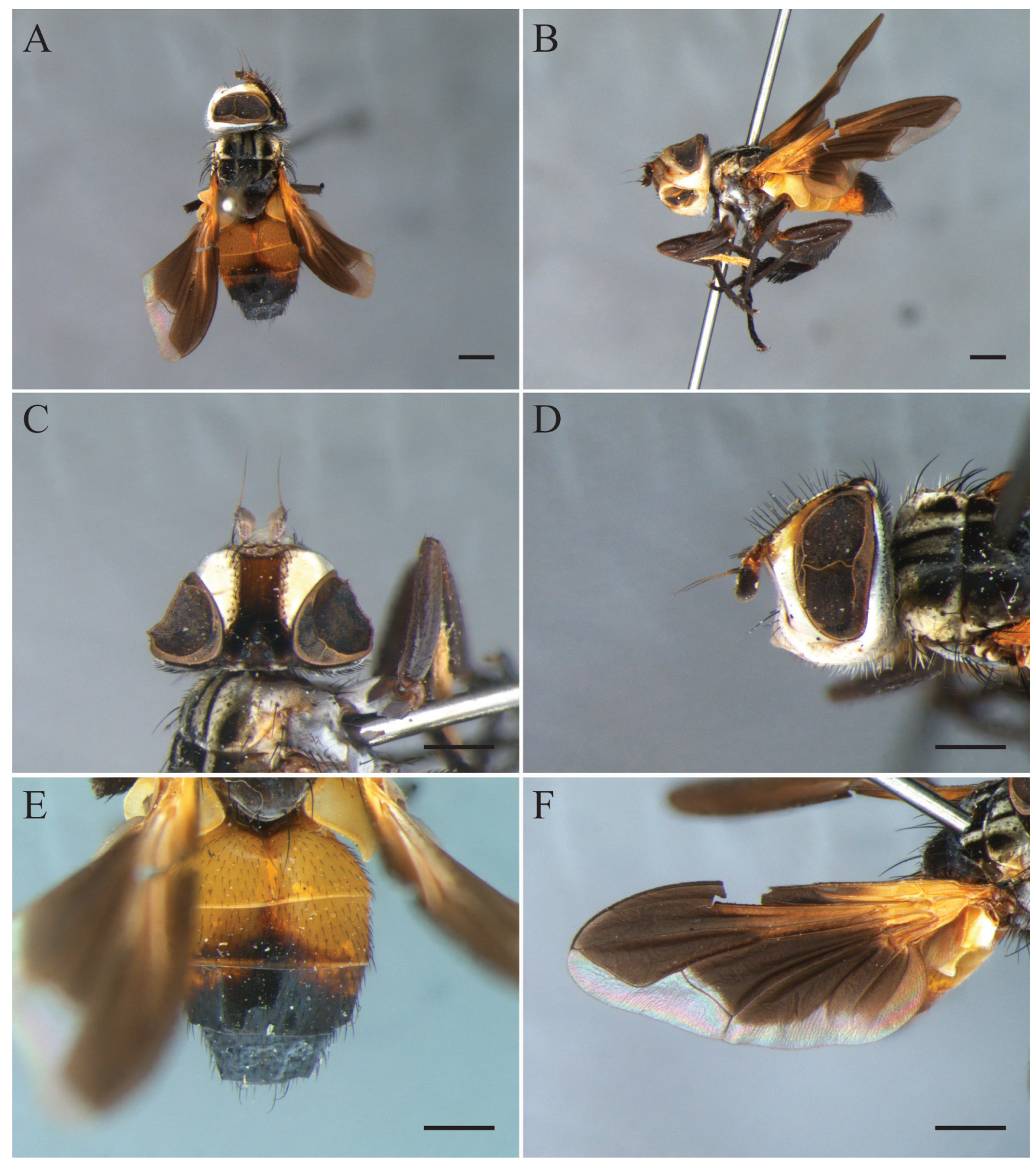

Fig. 8. Ectophasiopsis gradata (Wiedemann, 1830) comb. nov., ㅇ, Brazil, Nova Teutônia, DZUP. A. Dorsal view. B. Lateral view. C. Head, dorsal view. D. Head, lateral view. E. Abdomen, dorsal view. F. Wing, dorsal view. Scale bars: $1 \mathrm{~mm}$. 


\section{Ectophasiopsis ypiranga sp. nov. \\ urn:1sid:zoobank.org:act:082854A3-6E61-4232-8BBE-1B76302E379E}

Figs 1B, D, 2K-O, 3B, 4, 9-11

\section{Diagnosis}

Ectophasiopsis ypiranga sp. nov. differs from E. arcuata by having the antennal axis shorter and the fronto-orbital plate at the lunule level and parafacial narrowed, the thorax short setulose laterally and dorsally, and dorsocentral setae $1+2$.

Ectophasiopsis ypiranga sp. nov. closely resembles E. gradata comb. nov. in the thorax short setulose laterally and dorsally, dorsocentral setae 1+2, but E. gradata comb. nov. differs from E. ypiranga sp. nov. by having the antennal axis shorter; the fronto-orbital plate at the lunule level and parafacial narrowed; the cerci midventral opening lateral border visible in dorsal view, as a small lappet; and posterolateral lobes usually more developed.

\section{Etymology}

The specific epithet ypiranga is a noun in the indigenous language Tupi Guarani for 'red river' and it refers to the holotype location, nowadays a district in the city of São Paulo.

\section{Type material}

\section{Holotype}

BRAZIL: đ̊ [“S. Paulo - Ypiranga / Langer M. Morris / col. 29.iii.36"; "Holotype” (red label)], (CEIOC).

Paratypes (all with a green label)

BRAZIL: 1 ô (DZUP) ["Dpto Zool / UF - Paraná"; "Cáceres , MT / 9.i.1985 / C. Elias leg."; "Polonoroeste"; "DZUP / 251946"]; 1 ô, dissected (DZUP) ["Dpto Zool / UF - Paraná"; "Cáceres , MT / 20.iii.1985 / C. Elias leg."; "Polonoroeste"; "DZUP / 251956”]; 1 ○ (MZSP) [“Brasil:MT: Chap. Dos Guimarães / P. N. Chapada dos Guimarães / Cerrado - 577m - Trilha Cachoeira / Andorinha (Piscinas naturais) / S 15²4'51.5" W 5550'40.3" / Malaise 34 / 16-22.i.2012 / Lamas eq. col. / SISBIOTA / CNPq/FAPESP"]; 1 q (MZSP) [“Est. De Goiás / Corumbá / F. Monjolinho / Barreto col. / ii.945"]; 1 ð (DZUP) ["Jataí, Goiaz, i.1995 / M. Carrera, A. Machado / F. S. Pereira \& E. Dente / Milgar Loureiro col."; "DZUP / 252106"]; 1 ○ (CEIOC) ["Lagoa Santa / Minas Geraes / Lopes 27.ii.40". ^ (DZUP) "Dpto Zool / UF - Paraná"; "Araxá - Brasil / MG-22.11.1965 / C. T. Elias"; "DZUP / 252157”]; 1 q, ditto (DZUP), ["DZUP / 252120". + (DZUP) "Passos, MG / Brasil, v.1961 / C. Elias leg."; "DZUP /

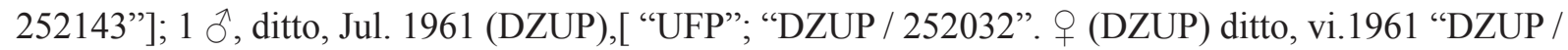
252149"]; 1 ठ̀, dissected, ditto, Sep. 1961 (DZUP), ["DZUP / 252136”]; 1 ○े, ditto, Oct. 1961(DZUP) [“DZUP / 252134". ㅇ (DZUP) ditto, "DZUP / 252142”]; 1 q, dissected (DZUP) ["Passos - Brasil / MG 1-30-x-61 / Claudionor Elias"]; 1 § (DZUP) [“Varginha / M. Gerais, Brasil / ix.1951 / M. Alvarenga leg."]; 1 ઈ, 1 क (MNHN) [“"Museum Paris / Brésil / Prov. de Minas Geraes / (2.100 m. d'altitude)/E. R. Wagner, 1902"]; 1 ðิ (USNM) [“Maracajú / Mato Grosso [do Sul]/ Brasil"; "Maio / 1937"; "Serviço

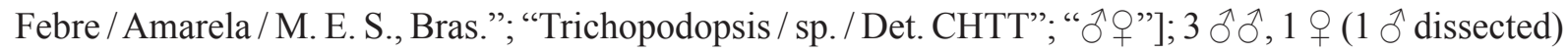
(USNM) ["Maracajú / Mato Grosso [do Sul]/ Brasil"; "Maio / 1937"; "Serviço Febre / Amarela / M. E. S., Bras."]; 1 \& (MZSP) ["Brasil, MS, Ponta Porã / 27.vii.2006 / No 3"]; 1 \& (MNHN) ["Guaratiba, D.F. Brasil / J. H. Guimarães / 1.8.1959"]; 1 q (MZSP) [“Est. R. Janeiro / Itatiaia / Campo Belo / Barreto

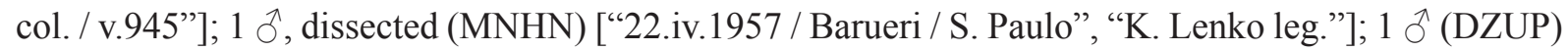
["São Paulo / Rio Claro - Jul.1939 / Pde. Pereira leg"]; 1 đo (DZUP) ["São Paulo / Rio Claro - Out.1939 / Pde. Pereira leg" \& (CEIOC) "S. José dos Campos / Est. S. Paulo / H. S. Lopes xii.934”]; 1 § (MNHN)

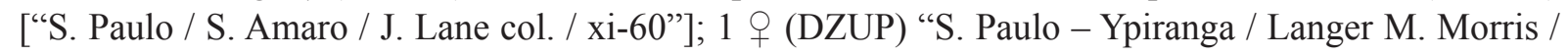


col. 31.iii.36"]; 1 ô, dissected (MNHN) ["Museum Paris / Chaco de Santiago / del Estero / bords du rio Salado / la Palisa del Bracho / 25 kil. N. O. d’Icaño / E. R. Wagner 1909”].

\section{Type locality}

BRAZIL: State of São Paulo, municipality of São Paulo, Ipiranga.

This species apparently has two distinct forms of males (see 'remarks' below). One darker and larger form, with light brown to tawny abdomen, with usually broader wings and abdomen, and another lighter color form, with abdomen more yellow, sometimes smaller in body size and with abdomen and wings usually narrower. The description below is based on a holotype representative of the large-dark form, and all variation found in this form and in the small-yellow form will be described separately. They are widely overlapping in their geographical range.

Male (Fig. 9)

Body LENGTH. $7.4 \mathrm{~mm}$.

Coloration. Frontal vitta light-tawny with region around ocellar triangle darker. Ocellar triangle black. Fronto-orbital plate light-tawny-yellow with light-golden to golden pruinosity. Parafacial light-tawnyyellow with light-golden pruinosity on upper half and silver pruinosity on lower half. Gena light-tawnyyellow with silver pruinosity. Scape and pedicel light-tawny-yellow; postpedicel light-brown with base and posterior part slightly orange-yellow. Palpus light-tawny to pale yellow. Presutural scutum covered with golden to light-golden pruinosity delimiting two diverging median black stripes fused anteriorly and two triangular lateral black spots. Postsutural scutum tawny to brown, light-tawny on sides, with light-golden pruinosity on sides and delimiting two median small triangular black spots; two long triangular black spots. Postalar callus with weak silver pruinosity. Scutellum dark brown to black with silver pruinosity. Thorax laterally brown to tawny with silver pruinosity. Wings with orange-yellow radiation from base to sc anteriorly, beyond vein $\mathrm{r}-\mathrm{m}$ medialy and little beyond vein bm-cu posteriorly; followed by infuscate band ranging from anal lobe almost to apex of wing, little beyond cell $r 4+5$, and posterior border hyaline; hyaline part extending to cell $\mathrm{dm}$. Calypters yellow-orange. Legs brown, coxae with silver pruinosity, trochanters and base of mid and hind-femora tawny-yellow; pulvilli pale-brown. Abdomen yellow; centrally shiny-light-brown on tergites 2 to 4 almost entirely, only lateral margins yellow; tergite 4 with brown median posterior line; tergite 5 brown centrally to light-brown laterally and yellow on laterals; tergite 6 yellow; tergite 5 and 6 with sparse silver pruinosity. Abdomen ventrally yellow, slightly darker on tip.

HEAD. Ratio of head width / thorax width dorsally of 1.45. Ratio of head length / head width 0.46 . Ratio of frontal vitta width at level of lunula / width at vertex level 0.6. Fronto-orbital plate width wider than frontal vitta width at level of lunula. Antennal axis short, fronto-orbital plate at lunule level and parafacial narrowed. Ratio of gena height / eye height 0.13 .

Thorax. Acrostichal setae 0+1; dorsocentral setae 1+1. Postpronotal lobe with 2 setae, one of them very weak. Two katepisternal setae.

Wing. Elliptical, anal lobe larger. Ratio of wing length/wing maximum width 2.8. Crossvein dm-cu straight, slightly sinuous.

LEGS. Hind femur with row of short anterodorsal setae on apical half and row of weak posteroventral setae on apical third; hind tibia with one median anteroventral seta and one median posterodorsal setae; row of longer feather-like setae covering apical 0.78 of tibia, length of longest feather-like seta 1.76 times tibial width. 
AвDOMEN. Elliptical and broad, dorsoventrally flattened. No differentiated setae. Ratio of abdomen length/thorax length 1.49. Ratio of abdomen width / thorax width 1.39. Ratio of abdomen length/ abdomen width 1.48 .

Terminalia (Fig. 2K-O). Cerci midventral opening lateral border visible in dorsal view, as a small lappet; posterolateral lobes usually more developed. Postgonite slightly enlarged distally in posterior view. Phallapodeme widened apically. Basiphallus forming a complete ring, fused posteriorly.

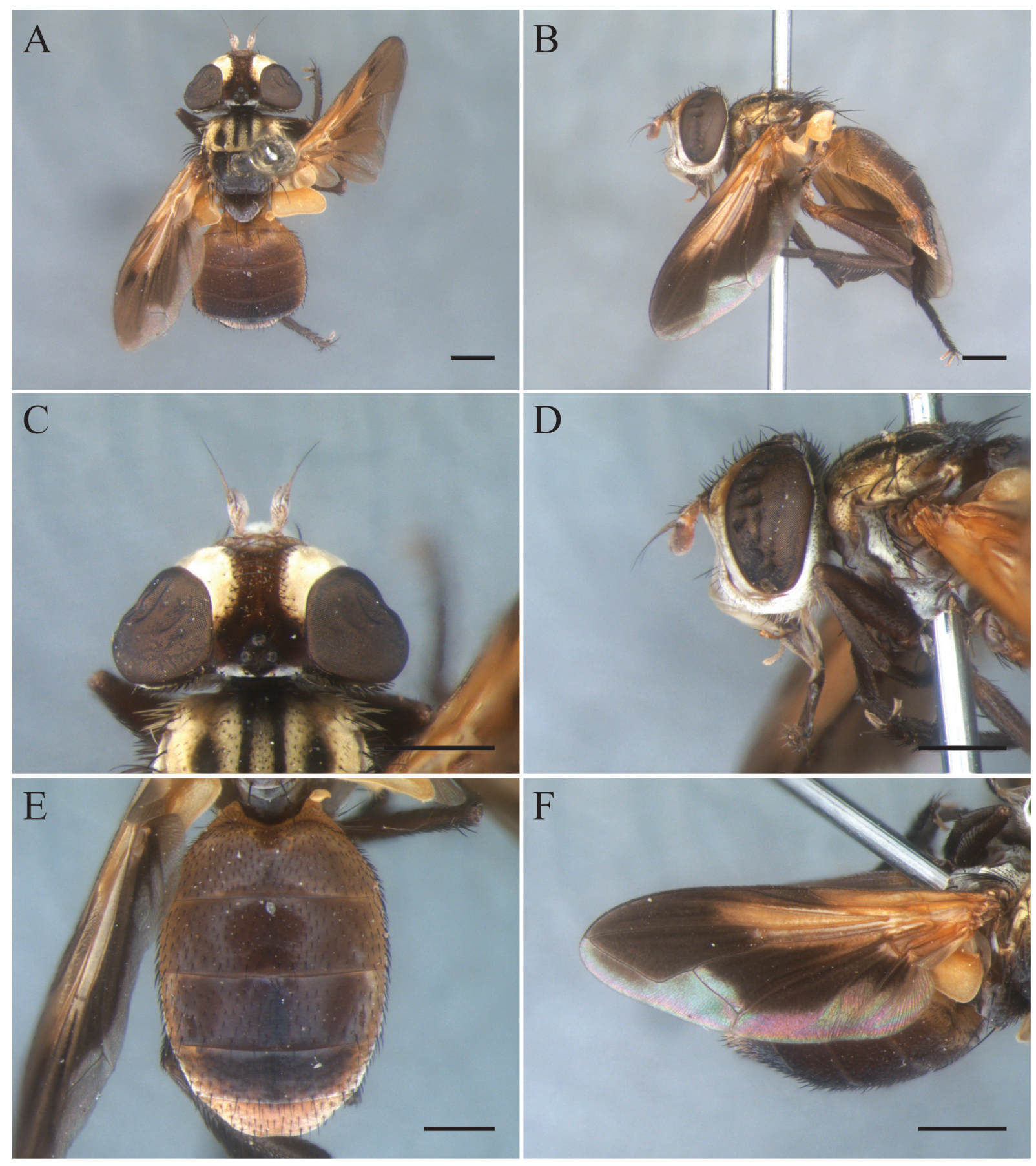

Fig. 9. Ectophasiopsis ypiranga sp. nov., ふ̂, holotype, Brazil, São Paulo, CEIOC. A. Dorsal view. B. Lateral view. C. Head, dorsal view. D. Head, lateral view. E. Abdomen, dorsal view. F. Wing, dorsal view. Scale bars: $1 \mathrm{~mm}$. 


\section{Variation in the large-dark form}

Body LENGTH. 7.4-8.0 mm $(\mathrm{n}=5)$.

Coloration. Frontal vitta and postpedicel darker. Presutural scutum covered with light-golden to silver pruinosity. Postpronotal lobe with light-golden to silver pruinosity. Postsutural scutum with silver pruinosity, sometimes only as two longitudinal thin lines. Scutellum lighter in ground color. Thorax laterally with light-golden pruinosity. Wings with radiation sometimes pale-yellow; infuscate band ranging little further but weakly infuscate; in this form the hyaline border entering cell $\mathrm{dm}$ is weakly distinguished. Calypters pale-yellow. Abdomen darker with yellow borders sometimes not distinguishable or narrower; brown to dark-brown median line ranging from tergites 2 to 4 or 3 to 4 ; tergite 4 sometimes dark-brown posteriorly; tergite 5 fully dark-brown; tergite 6 yellow to tawny, sometimes with brown markings; or fully tawny to brown.

HEAD. Ratio of head width/thorax width dorsally 1.36 to 1.5 . Ratio of frontal vitta width at level of lunula/width at vertex level 0.6 to 0.74 . Ratio of gena height/ eye height 0.13 to 0.17 . Wing. Ratio of wing length/wing maximum width 2.41 to 2.8 .

LEGS. Hind femur with row of short anterodorsal setae very weak; hind tibia with row of longer feather-like setae covering apical 0.77 to 0.84 of tibia, length of longest feather-like seta 1.42 to 1.76 times tibial width.

AвDOMEN. Ratio of abdomen width/thorax width 1.3 to 1.49. Ratio of abdomen length/abdomen width 1.43 to 1.57 .

Variation in the small-yellow form (Fig. 11)

Body LENGTH. 5.8-7.2 mm $(\mathrm{n}=5)$.

Coloration. Fronto-orbital plate with light-golden to silver pruinosity. Presutural scutum covered with light-golden to silver pruinosity. Postpronotal lobe with light-golden to silver pruinosity. Wings with infuscate band always well defined, hyaline border wider. Abdomen yellow, sometimes fully, or yellow with brown markings: brown to dark-brown median line from tergites 3 to 5 or 4 to 5 , varying in intensity; tergite 4 with small markings and tergite 5 with larger markings, sometimes almost entirely brown; one specimen with all abdomen covered with brown markings; all variations can have silver pruinosity on tergites 5 and 6 .

THORAX. Postpronotal lobe sometimes with 1 seta.

WING. Elliptical, anal lobe sometimes not large. Ratio of wing length/wing maximum width 2.62 to 2.85. Lower calypter external lobe sometimes less enlarged.

LEGS. Hind femur with row of short anterodorsal setae on apical half, sometimes not differentiated or very weak, and row of weak posteroventral setae on apical third sometimes very weak; length of longest feather-like seta 1.51 to 2.14 times tibial width.

ABdomen. Elliptical, sometimes narrower (ratio of abdomen width/thorax width 1.22 to 1.38), slightly longer (ratio of abdomen length/thorax length 1.46 to 1.64 ), less dorsoventrally flattened.

Female (Fig. 10)

The female is almost entirely similar to the small, yellow male form, differing from it as follows:

Body LENGTH. 5.9-7.0 mm $(\mathrm{n}=5)$. 
Coloration. Abdomen with tergite 3 sometimes with brown markings posteriorly; tergite 4 with small triangular median posterior markings or all infused with brown varying in intensity; tergite 6 brown to black, rarely light tawny; rarely abdomen almost fully yellow.

ABdomen. Sometimes slightly ovate.

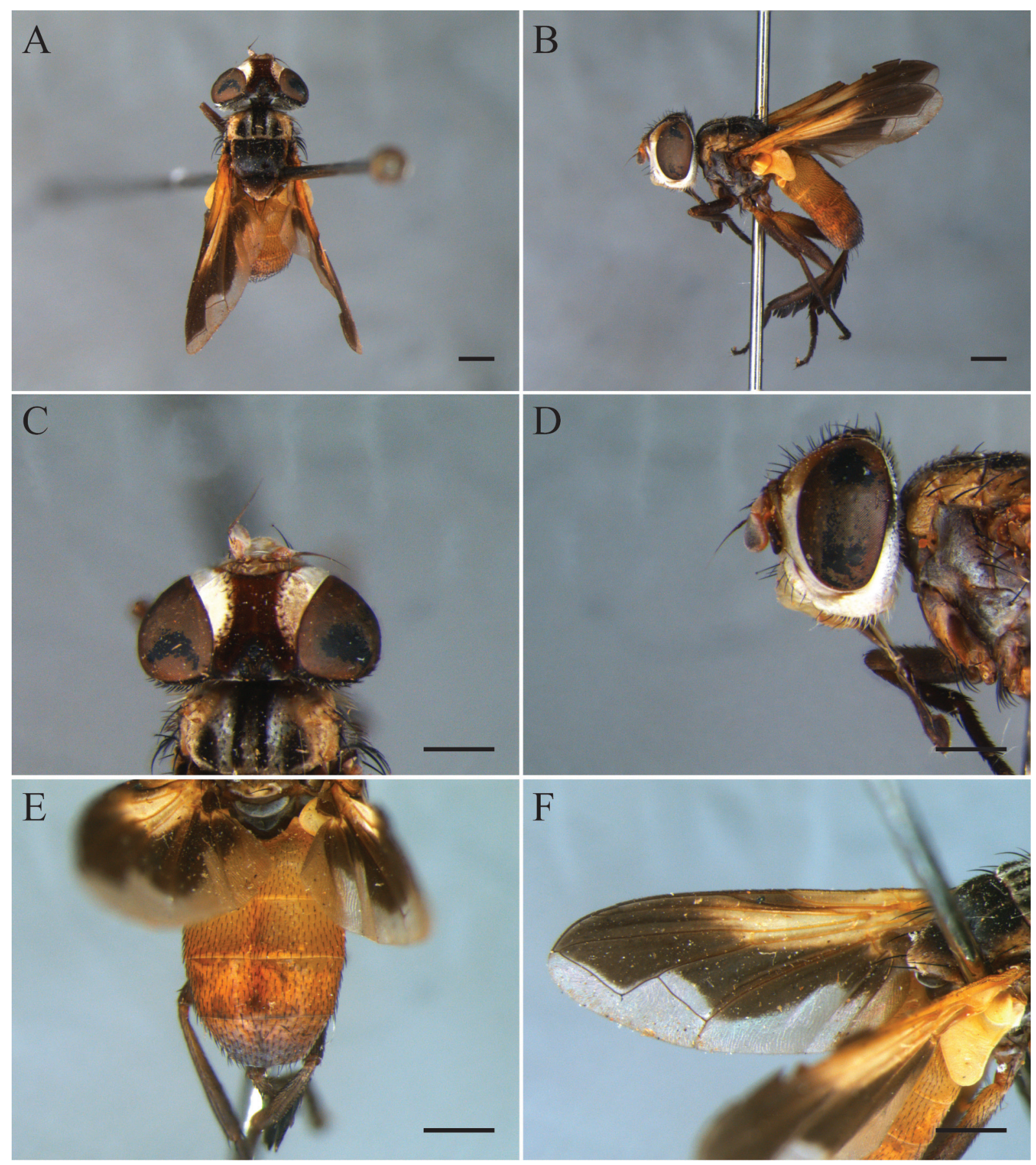

Fig. 10. Ectophasiopsis ypiranga sp. nov.,, , paratype, Brazil, Passos, DZUP. A. Dorsal view. B. Lateral view. C. Head, dorsal view. D. Head, lateral view. E. Abdomen, dorsal view. F. Wing, dorsal view. Scale bars: $1 \mathrm{~mm}$. 
Terminalia (Fig. 3B). Sternite 8 short, slightly slenderer and longer than in E. gradata comb. nov., rounded distally, with small membranous invagination ventrally.

\section{Distribution (Fig. 4)}

Brazil (Mato Grosso, Goiás, Minas Gerais, Mato Grosso do Sul, Rio de Janeiro, São Paulo), and Argentina.


Fig. 11. Ectophasiopsis ypiranga sp. nov., đ̂, paratype, Brazil, Maracajú, USNM. A. Dorsal view. B. Lateral view. C. Head, dorsal view. D. Head, lateral view. E. Abdomen, dorsal view. F. Wing, dorsal view. Scale bars: $1 \mathrm{~mm}$. 


\section{Remarks}

This species exhibits polymorphism and two male forms are recognizable: 1) a large and dark form, with darker abdomen and wings, wings slightly larger; and 2) a smaller and paler form, which resembles the females, with light abdomen and wings, and wings as in females. To avoid any further confusion concerning the identity of this species, the holotype designated here was selected among a male representative of the large-dark form, with the description based on the dark-large male form, and the small-yellow male form is described in the 'Variation' section. The male polymorphism observed in E. ypiranga sp. nov. is better discussed in the Discussion section of this publication.

\section{Ectophasiopsis host list}

Below we present an updated list of records found during the course of this revision since Guimarães (1977), as well as new records:

\section{Ectophasiopsis arcuata}

Hemiptera: Pentatomidae:

Acledra albocostata (Spinola, 1852): Guimarães (1977).

Acledra dimidiaticollis (Spinola, 1852): Guimarães (1977).

Nezara viridula (Linnaeus, 1758): Jones (1988) (Chile); Ripa et al. (1995) (Easter Island).

\section{Ectophasiopsis gradata comb. nov.}

Hemiptera: Coreidae:

Athaumastus haematicus (Stål, 1860): Guimarães (1977); Liljesthröm (1992) (Argentina, Buenos Aires).

Hemiptera: Pentatomidae:

Dichelops furcatus (Fabricius, 1775): new record (Brazil, Rio Grande do Sul; Uruguay, Paysandú).

Dichelops melacanthus (Dallas, 1851): new record (Brazil, Paraná).

\section{Ectophasiopsis ypiranga sp. nov.}

No host records.

\section{Discussion}

Considering the fact that Ectophasiopsis was so far known by its original description (Townsend 1915) only, the detailed descriptions and illustrations provided in this revision, after 101 years, will improve our understanding of this obscure genus and closely related taxa. With the present revision, two species (a new combination and a new species) are added to the previously monotypic genus Ectophasiopsis. Its systematic placement was controversial, but now is allocated in the tribe Gymnsomatini, close to the former genera of Trichopodini, mainly based on characters of male and female terminalia: the characteristic fused cerci and the asymmetric, complex distiphallus in the male, and the plate-like cerci and characteristic weakly sclerotized sternite 8 in the female, common features in many species of Trichopodini. Male and female terminalia had not been described before for Ectophasiopsis, although Verbeke (1962: plate XIV, fig. 3) illustrated the male terminalia of "Trichopoda sp." that is probably a misidentification, as the characteristic ring-like plate of Ectophasiopsis is noticeable.

Ectophasiopsis shares some characteristics with Trichopoda, but also has some distinct features as mentioned in the identification key (in head structure and coloration, wing venation and color pattern, and claw coloration), in addition to differences in the male terminalia (mainly related to the ring-shaped distiphallus). Considering these distinctive features, we consider Ectophasiopsis to be a valid genus. Additional sampling from different places in South America will quite probably produce more species of Ectophasiopsis. Moreover, further phylogenetic studies using a wide range of characters (morphological 
and molecular) and including a more representative Neotropical sampling of Gymnosomatini, where most genera and species occur, will contribute towards a better understanding of the supra-generic relationships and generic delimitations.

Here, we also report a possible male polymorphism for Ectophasiopsis ypiranga sp. nov., one of the first reports in Tachinidae. Dimorphism in males has been observed in more than 200 insect species of 11 different orders, and in some species male dimorphism is related to the mating system and, therefore, related to sexual selection (Buzatto et al. 2014). In this scenario, the occurrence of alternative reproductive tactics could be expected, where one gender uses alternative ways, such as different behavior or sperm competition, to achieve fertilization (Taborsky et al. 2008). These alternative tactics could be related to the occurrence of alternative phenotypes. Alternative reproductive tactics are expected to evolve more often within males because of the higher investment from females (Taborsky et al. 2008). This question could be tested and better understood in further studies. The two forms of E. ypiranga sp. nov. are described as conspecific based on similarities in the male terminalia, while the female is very uniform throughout the distributional range of the species. On the other hand, it is possible that this species represents a complex of cryptic species, which may be better tested with molecular studies.

\section{Acknowledgements}

We wish to thank the curators of the depository institutions for the loan of material: Nigel Wyatt (BMNH), Victor Smith (CAS), Jane Costa (CEIOC), Cláudio Carvalho (DZUP), Ruben La Rossa (INTA), Christophe Daugeron (MNHN), Carlos Lamas (MZSP), Norman Woodley (USNM) and Joachim Ziegler (ZMHB); moreover also Peter Sehnal (NHMW) for kindly taking and sending the photos of the holotype of Trichopoda gradata comb. nov. and Ricardo Panizzi (EMBRAPA - Trigo), Nelson Perioto (APTA Ribeirão Preto) and Enrique Castiglioni and Jerson Guedes (UFSM) for kindly sending material for study. We also thank Adrian Pont and the Oxford University Museum of Natural History (OUMNH) for sharing with us Verrall's handwritten notes on the Bigot type collection, which was helpful in taking the decision about Bigot's types. We are thankful to Rachel Werneck for her comments and suggestions on the male dimorphism. We want to thank all the anonymous reviewers of this manuscript since the beginning, editors and everyone that helped during the entire process of this revision. We also acknowledge the scholarship grant to Rodrigo de Vilhena Perez Dios from CNPq (proc. n. 130204/2012-9). Financial support to Silvio Shigueo Nihei from FAPESP (proc. n. 2007/508367 and 2013/05131-6) and CNPq fellowship (proc. n. 303615/2015-0).

\section{References}

Aldrich J.M. 1934. Tachinidae. In: Alexander C.P. (ed.) Diptera of Patagonia and South Chile based mainly on material in British Museum (Natural History). Bulletin of the British Museum (Natural History) 7 (1): 1-70.

Bigot J.M.F. 1876. Diptères nouveaux ou peu connus, 6e partie, VIII: Curie dês Phasides (Phasidae, mihi). Genres Trichopoda (Macq.) et Bogosia (Rond.). Annales de la Société Entomologique de France 5 (6): 389-400.

Blanchard E.E. 1966. Nuevos triquiopodinos argentinos, parasitos de hemípteros nocivos. (Dipt. Gymnosomatidae). Revista de Investigaciones Agrapecuarias 5 (Patologia Vegetal) (3) 7: 59-95.

Brauer F. 1898. Beiträge zur Kenntniss der Muscaria Schizometopa. Sitzungsberichte der Akademie der Wissenschaften, Mathematisch-Naturwissenschaftliche Classe 107 (1): 493-546.

Buzatto B.A., Tomkins J.L. \& Simmons L.W. 2014. Alternative phenotypes within mating systems. In: Shuker D. \& Simmons L. (eds) The Evolution of Insect Mating Systems: 106-128. Oxford University Press, Oxford, United States. https://doi.org/10.1093/acprof:oso/9780199678020.003.0007 
Cerreti P., O’Hara J.E., Wood D.M., Shima H. Inclan D.J. \& Stireman J.O. 2014. Signal through the noise? Phylogeny of the Tachinidae (Diptera) as inferred from morphological evidence. Systematic Entomology 39: 335-353. https://doi.org/10.1111/syen.12062

Crosskey R.W. 1971. The type material of Australasian, Oriental and Ethiopian Tachinidae (Diptera) described by Macquart and Bigot. Bulletin of the British Museum (Natural History) Entomology 25: 253-305.

Cumming J.M. \& Wood D.M. 2009. Adult morphology and terminology. In: Brown B.V., Borkent A., Cumming J.M., Wood D.M., Woodley N.E. \& Zumbado M.A. (eds) Manual of Central American Diptera, Volume 1: 9-50. NRC Research Press, Ottawa, Canada.

Dios R.V.P. \& Nihei S.S. 2016. A remarkable new species of Eutrichopoda Townsend, 1908 (Diptera: Tachinidae: Phasiinae). Zootaxa 4121 (2): 194-200. https://doi.org/10.11646/zootaxa.4121.2.10

Dupuis C. 1963. Essai monographique sur les Phasiinae. Mémoires du Muséum national d'Histoire naturelle A (26): 1-461.

Guimarães J.H. 1971. Family Tachinidae (Larvaevoridae). A catalogue of the Diptera of the Americas south of the United States. In: Papavero N. (ed.) A catalogue of the Diptera of Americas South of the United States: 1-333. Depto. de Zoologia, Secretaria da Agricultura, São Paulo, Brazil.

Guimarães J.H. 1977. Host-parasite and parasite-host catalogue of South American Tachinidae (Diptera). Arquivos de Zoologia 28 (3): 1-131.

Jones W.A. 1988. World review of the parasitoids of the southern green stink bug, Nezara viridula (L.) (Heteroptera: Pentatomidae). Annals of Entomological Society of America 81 (2): 262-273. https://doi. org/10.1093/aesa/81.2.262

Kozub D., Khmelik V., Shapoval J., Chentsov V., Yatsenko S., Litovchenko B. \& Starikh V. 2000-2013. Helicon Focus 5.3.14. Helicon Soft Ltd. Available from http://www.heliconsoft.com/helicon-focushistory-of-changes-win/ [accessed 31 May 2017].

Liljesthröm G.G. 1992. Revision de las espécies de los gêneros Trichopoda Berthold, Trichopodopsis Townsend y Eutrichopodopsis Blanchard descriptas para la Republica Argentina. Revista de la Sociedad Entomológica Argentina 50 (1-4): 51-71.

QGIS Development Team. 2014. QGIS Geographic Information System. Open Source Geospatial Foundation Project. Available from http://qgis.osgeo.org [accessed 11 May 2017].

Ripa S.W., Rojas P.S. \& Velasco G. 1995. Releases of biological control agents of insects pests on Easter Island (Pacific Ocean). Entomophaga 40 (3-4): 427-440.

Sabrosky C.W. 1950. Notes on Trichopodini (Diptera, Larvaevoridae); with description of a new parasite of cotton stainers in Puerto Rico. Journal of the Washington Academy of Sciences 40: 361-371.

Stuckenberg B.R. 1999. Antennal evolution in the Brachycera (Diptera), with a reassessment of terminology relating to the flagellum. Studia dipterologica 6: 33-48. https://doi.org/10.5281/ zenodo. 12390

Taborsky M., Oliveira R.F. \& Brockmann H.J.B. 2008. The evolution of alternative reproductives tactics: concepts and questions. In: Oliveira R.F., Taborsky M. \& Brockmann H.J. (eds) Alternative Reproductive Tactics: an Integrative Approach: 1-21. Cambridge University Press, Cambridge, United States. https://doi.org/10.1017/CBO9780511542602.002

Townsend C.H.T. 1893. On the geographic range and distribution of the genus Trichopoda. Entomological News and Proceedings of the Entomological Section of the Academy of Natural Sciences of Philadelphia 4 (3): 69-71. 
Townsend C.H.T. 1915. New Neotropical muscoid flies. Proceedings of the National Museum 49 (2115): 405-440. https://doi.org/10.5479/si.00963801.2115.405

Townsend C.H.T. 1936. Manual of Myiology, in Twelve Parts. Part III. Oestroid Classification and Habits. Gymnosomatidae to Tachinidae. Townsend \& Filhos, Itaquaquecetuba.

Townsend C.H.T. 1938. Manual of Myiology, in Twelve Parts. Part VII. Oestroid Generic Diagnoses and Data. Townsend \& Filhos, Itaquaquecetuba.

Tschorsnig H.P. 1985. Taxonomie förstlich wichtiger Parasiten: Untersuchungen zur Struktur des männlichen Postabdomens der Raupenfliegen (Diptera, Tachinidae). Stuttgarter Beiträge zur Naturkunde, Serie A, Biologie 383: 1-137.

Verbeke J. 1962. Contribution à l'étude des Tachinidae africains (Diptera). 1. Description et valeur taxonomique des genitalia males. 2. Imitomyiini, Palpostomatini et Ethyllini nouveaux ou peu connus. Résultats Scientifiques Exploration Hydrobiologique des Lacs Kivu, Édouard et Albert 3 (4): 77-187.

Walker F 1853. Diptera. Part IV. In: Saunders W.W. (ed.) Insecta Saundersiana: or Characters of Undescribed Insects in the Collection of William Wilson Sauders, Vol. 1: 253-414. Van Voorst, London.

Wiedemann C.R.W. 1830. Außereuropäische zweiflügelige Insekten. Zweiter Theil. Schulz, Hamm. https://doi.org/10.5962/bhl.title.14603

Wolcott G.N. 1948. The insects of Puerto Rico. Diptera. Journal of Agriculture of the University of Puerto Rico 32: 417-532.

Manuscript received: 22 June 2016

Manuscript accepted: 21 October 2016

Published on: 4 July 2017

Topic editor: Gavin Broad

Desk editor: Kristiaan Hoedemakers

Printed versions of all papers are also deposited in the libraries of the institutes that are members of the EJT consortium: Muséum national d'Histoire naturelle, Paris, France; Botanic Garden Meise, Belgium; Royal Museum for Central Africa, Tervuren, Belgium; Natural History Museum, London, United Kingdom; Royal Belgian Institute of Natural Sciences, Brussels, Belgium; Natural History Museum of Denmark, Copenhagen, Denmark; Naturalis Biodiversity Center, Leiden, the Netherlands; Museo Nacional de Ciencias Naturales-CSIC, Madrid, Spain; Real Jardín Botánico de Madrid CSIC, Spain. 